Research

\title{
Clinical relevance of and risk factors for HSV-related tracheobronchitis or pneumonia: results of an outbreak investigation
}

\author{
Ilka Engelmann1, Jens Gottlieb², Astrid Meier ${ }^{3}$, Dorit Sohr4, Arjang Ruhparwar5,6, Cornelia Henke- \\ Gendo1, Petra Gastmeier ${ }^{3}$, Tobias Welte ${ }^{2}$, Thomas Friedrich Schulz ${ }^{1}$ and Frauke Mattner ${ }^{3}$
}

\author{
${ }^{1}$ Institute of Virology, Medizinische Hochschule Hannover, Carl-Neuberg-Strasse 1, 30625 Hannover, Germany \\ 2Department of Pneumology, Medizinische Hochschule Hannover, Carl-Neuberg-Strasse 1, 30625 Hannover, Germany \\ 3 Institute of Medical Microbiology and Hospital Epidemiology, Medizinische Hochschule Hannover, Carl-Neuberg-Strasse 1, 30625 Hannover, \\ Germany \\ ${ }^{4}$ Institute of Hygiene and Hospital Epidemiology, Charité, Hindenburgdamm 2712203 Berlin, Germany \\ 5 Division of Thoracic and Cardiovascular Surgery, Medizinische Hochschule Hannover, Carl-Neuberg-Strasse 1, 30625 Hannover, Germany \\ ${ }^{6}$ Department of Cardiac Surgery, University of Heidelberg, Im Neuenheimer Feld 110, 69120 Heidelberg, Germany
}

Corresponding author: Ilka Engelmann, engelmann.ilka@mh-hannover.de

Received: 5 Jun 2007 Revisions requested: 9 Jul 2007 Revisions received: 24 Aug 2007 Accepted: 8 Nov 2007 Published: 8 Nov 2007

Critical Care 2007, 11:R119 (doi:10.1186/cc6175)

This article is online at: http://ccforum.com/content/11/6/R119

(c) 2007 Engelmann et al, licensee BioMed Central Ltd.

This is an Open Access article distributed under the terms of the Creative Commons Attribution License (http://creativecommons.org/licenses/by/ 2.0), which permits unrestricted use, distribution, and reproduction in any medium, provided the original work is properly cited.

\begin{abstract}
Introduction Herpes simplex virus (HSV) type 1 was identified in respiratory specimens from a cluster of eight patients on a surgical intensive care unit within 8 weeks. Six of these patients suffered from HSV-related tracheobronchitis and one from HSVrelated pneumonia only. Our outbreak investigation aimed to determine the clinical relevance of and risk factors associated with HSV-related tracheobronchitis or pneumonia in critically ill patients, and to investigate whether the cluster was caused by nosocomial transmission.
\end{abstract}

Methods A retrospective cohort study was performed to identify risk factors for the outcomes of HSV-related tracheobronchitis or pneumonia and death using univariable analysis as well as logistic regression analysis. Viruses were typed by molecular analysis of a fragment of the HSV type 1 glycoprotein G.

Results The cohort of patients covering the outbreak period comprised 53 patients, including six patients with HSV-related tracheobronchitis and one patient with pneumonia only. HSVrelated tracheobronchitis or pneumonia was associated with increased mortality $(100 \%$ in patients with versus $17.8 \%$ in patients without HSV-related tracheobronchitis or pneumonia; $P$ $<0.0001)$. The interaction of longer duration of ventilation and tracheotomy was associated with HSV-related tracheobronchitis or pneumonia in multivariable analysis.

Identical HSV type 1 glycoprotein G sequences were found in three patients and in two patients. The group of three identical viral sequences belonged to a widely circulating strain. The two identical viral sequences were recovered from bronchoalveolar lavages of one patient with HSV-related tracheobronchitis and of one patient without clinical symptoms. These viral sequences showed unique polymorphisms, indicating probable nosocomial transmission.

Conclusion HSV-related tracheobronchitis or pneumonia is associated with increased mortality in critically ill patients. Care should be taken to avoid nosocomial transmission and early diagnosis should be attempted.

\section{Introduction}

Herpes simplex virus (HSV) is a double-stranded DNA virus occurring in two types, HSV-1 and HSV-2. Transmission usually occurs by contact with infected saliva or cutaneous lesions [1]. After primary infection, HSV-1 establishes a life-long latent infection through persistence in neurons of the dorsal root ganglia and the autonomic nervous system [2]. Reactivation can be triggered by local stimuli (ultraviolet irradiation, tissue damage) or by systemic stimuli (fever, menstruation, surgery, physical or emotional stress, hormonal imbalance,

$\mathrm{bp}=$ base pair; $\mathrm{HSV}=$ herpes simplex virus; $\mathrm{SICU}=$ surgical intensive care unit; $\mathrm{PCR}=$ polymerase chain reaction. 
immunosuppression) [3]. Clinical manifestations of HSV-1 infection include gingivostomatitis (primary infection), herpes labialis, encephalitis, and keratoconjunctivitis; infections of the respiratory or gastrointestinal tract have been described predominantly in immunosuppressed patients [2].

Asymptomatic shedding of HSV in healthy individuals has been reported to occur in $2-10 \%$ of infected individuals $[4,5]$. HSV-1 can be detected in the upper respiratory tract and in the lower respiratory tract of intensive care unit patients in 22$23 \%$ and $16 \%$ of cases, respectively $[5,6]$. Whether these proportions represent clinically relevant HSV infection or, rather, are an indicator of severe disease favouring reactivation without clinical significance is the subject of ongoing debate [5,7-9]. Tracheobronchitis due to HSV has been described in critically ill patients $[10,11]$.

As more than $90 \%$ of adults have antibodies specific for HSV1 [11], infections in adulthood are usually assumed to be reactivation of endogenous virus, although reinfection with a different HSV-1 strain that is immunologically distinct is also possible [12].

Eight patients in a surgical intensive care unit (SICU) had HSV-1 detected in their respiratory tract within 8 weeks. Tracheobronchitis was associated with HSV-1 detection in six patients and with pneumonia in four patients. This cluster prompted us to investigate the clinical impact of HSV-related tracheobronchitis or pneumonia and to identify risk factors predisposing to HSV-related tracheobronchitis or pneumonia and fatal outcome. As the cluster suggested the possibility of nosocomial transmission, molecular epidemiological studies were performed to type all viruses recovered from the patients.

\section{Materials and methods}

\section{Setting and patients}

When a cluster of six patients with HSV-1-related tracheobronchitis occurred on a 15-bed cardiothoracic SICU (Figure
1), the present outbreak investigation was initiated. Medical records of the SICU and the database of the Department of Virology were reviewed to identify all patients who were hospitalized on this SICU during the time period when the cluster occurred and who had HSV-1 detected (by antigen detection, virus isolation or $\mathrm{PCR}$ ) in respiratory fluids.

Demographic data as well as underlying diseases, clinical course, any severe clinical presentations in addition to the HSV-1-associated ones and outcome were recorded (Tables 1 and 2). All records of bronchoscopic and radiologic examinations were reassessed, focusing on endobronchial bleedings and lesions or infiltrates compatible with HSV infection. Microbiological and mycological findings were reviewed to determine whether concurrent infections with pathogens other than HSV were present. To assess the clinical relevance of HSV-1 detection in respiratory fluids, the clinical presentations and outcomes of HSV-1-positive patients were analysed (Tables 1 and 2).

Bronchoscopies were sampled after routine disinfection. DNA was isolated and used as the input in the diagnostic HSV PCR and in the typing PCR (see below).

The institutional review board approved the outbreak investigation.

\section{Cohort study}

A retrospective cohort study was performed including the 8week period that entirely covered the cluster episode. During this period all patients admitted to the SICU with a stay longer than 72 hours were included $(n=53)$. The analysed outcomes were death and HSV-related tracheobronchitis or pneumonia. The latter was defined as HSV detection in the respiratory tract concomitant with the presence of tracheobronchitis or pneumonia and an absence of other respiratory pathogens even though histopathology was not performed. Sampling for HSV detection in respiratory fluids was performed if clinically

Figure 1

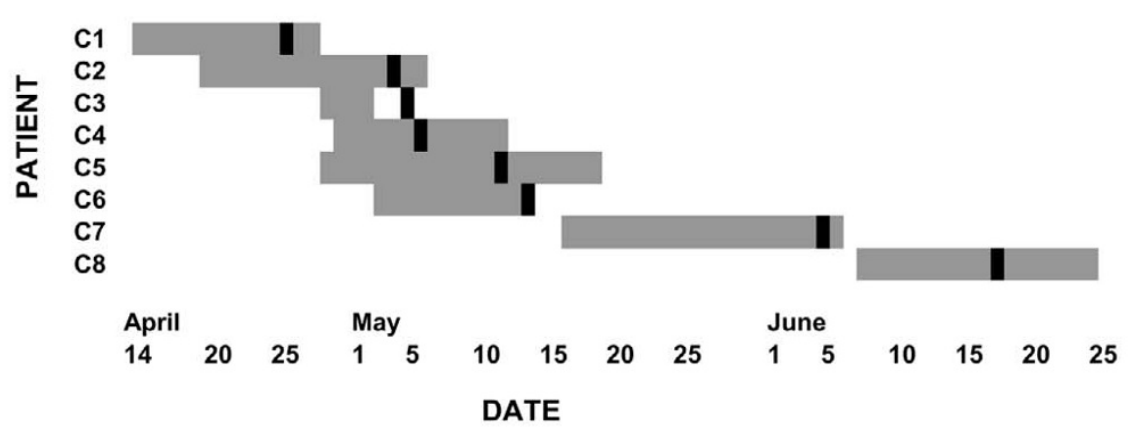

Patient cluster with herpes simplex virus in respiratory specimens on the surgical intensive care unit. Grey bars, period of stay on the surgical intensive care unit; black bars, day when herpes simplex virus type 1 was detected in the respiratory tract of the patient. 
Table 1

Demographic and clinical characteristics of patients with herpes simplex virus type 1 detection in respiratory specimens

\begin{tabular}{|c|c|c|c|c|c|}
\hline $\begin{array}{l}\text { Cluster } \\
\text { Patient/lsolate }\end{array}$ & Gender & Age (years) & Underlying disease & Surgical procedure & $\begin{array}{l}\text { Herpes simplex virus-associated } \\
\text { infection }\end{array}$ \\
\hline $\mathrm{C} 1$ & Female & 81 & Aortic stenosis & $\begin{array}{l}\text { Replacement of the aortic valve } \\
\text { by biological graft }\end{array}$ & $\begin{array}{l}\text { Pneumonia, haemorrhagic } \\
\text { tracheobronchitis }\end{array}$ \\
\hline $\mathrm{C} 2$ & Male & 74 & $\begin{array}{l}\text { Infection of the aortic Y- } \\
\text { prosthesis }\end{array}$ & Replacement of the aorta & Haemorrhagic tracheobronchitis \\
\hline C3 & Female & 18 & Cystic fibrosis & Lung transplantation & - \\
\hline $\mathrm{C} 4$ & Male & 78 & Coronary heart disease & Coronary artery bypass graft & Haemorrhagic tracheobronchitis \\
\hline C5 & Male & 61 & Coronary heart disease & Coronary artery bypass graft & $\begin{array}{l}\text { Pneumonia, haemorrhagic } \\
\text { tracheobronchitis }\end{array}$ \\
\hline C6 & Male & 51 & Coronary heart disease & $\begin{array}{l}\text { Extracorporeal membrane } \\
\text { oxygenation implantation }\end{array}$ & Haemorrhagic tracheobronchitis \\
\hline $\mathrm{C} 7$ & Male & 67 & $\begin{array}{l}\text { Covered rupture of an aortic } \\
\text { aneurysm }\end{array}$ & Replacement of the aorta & $\begin{array}{l}\text { Pneumonia, haemorrhagic } \\
\text { tracheobronchitis }\end{array}$ \\
\hline C8 & Male & 77 & Coronary heart disease & Coronary artery bypass graft & Pneumonia \\
\hline
\end{tabular}

Table 2

\section{Clinical and virologic characteristics of patients with herpes simplex virus type 1 detection in respiratory specimens}

\begin{tabular}{|c|c|c|c|c|c|c|}
\hline \multirow{2}{*}{$\begin{array}{l}\text { Cluster } \\
\text { Patient/ } \\
\text { Isolate }\end{array}$} & \multirow{2}{*}{$\begin{array}{l}\text { Clinical presentation besides herpes simplex virus- } \\
\text { associated presentations }\end{array}$} & \multicolumn{4}{|c|}{ Herpes simplex virus detection } & \multirow[t]{2}{*}{ Outcome } \\
\hline & & Specimen type & $\begin{array}{l}\text { Direct } \\
\text { immunofluorescence } \\
\text { testing }\end{array}$ & Virus culture & PCR & \\
\hline $\mathrm{C} 1$ & Right-sided heart failure & Tracheal aspirate & - & - & + & Death \\
\hline $\mathrm{C} 2$ & $\begin{array}{l}\text { Infection of the aortic Y-prosthesis, intraabdominal } \\
\text { bleedings }\end{array}$ & Bronchoalveolar lavage & + & + & + & Death \\
\hline C3 & - & Bronchoalveolar lavage & + & - & + & Survival \\
\hline $\mathrm{C} 4$ & $\begin{array}{l}\text { Adult respiratory distress syndrome, internal carotid } \\
\text { artery stenosis }\end{array}$ & Tracheal aspirate & + & + & + & Death \\
\hline C5 & Adult respiratory distress syndrome & Nasopharyngeal swab & + & + & + & Death \\
\hline C6 & - & Bronchoalveolar lavage & + & + & + & Death \\
\hline C7 & Peritonitis with coagulase-negative Staphylococci & Bronchoalveolar lavage & + & + & + & Death \\
\hline $\mathrm{C} 8$ & Sepsis & Bronchoalveolar lavage & + & + & + & Death \\
\hline
\end{tabular}

indicated (that is, in case of unexplained deterioration of respiratory function, tracheobronchial bleeding or suspicious mucosal lesions on bronchoscopic examination).

Of the 53 patients, seven fulfilled the criteria for the outcome HSV-related tracheobronchitis or pneumonia. One of the patients with HSV detection in bronchoalveolar lavage was excluded from the analysis of the cohort study (Patient C3) because he did not show symptoms related to HSV (Tables 1 and 2). The HSV glycoprotein G sequence of this patient was included in the molecular epidemiological analysis (see below). None of the remaining 45 patients presented with symptoms of tracheobronchitis. Eight of the 45 remaining patients were confirmed negative for HSV in their lower respiratory tract secretions, whereas the other patients were not tested because testing was only performed if clinical symptoms were evocative.

The variables analysed as risk factors for HSV-related tracheobronchitis or pneumonia and fatal outcome are presented in Tables 3 and 4. The variables pneumonia and HSV-related tracheobronchitis or HSV-related pneumonia were included 
Table 3

Frequency of outcome herpes simplex virus type 1 (HSV-1)-related tracheobronchitis or pneumonia depending on patient characteristics and extrinsic risk factors

\begin{tabular}{|c|c|c|c|c|c|c|}
\hline \multirow[t]{2}{*}{ Risk factor } & \multicolumn{2}{|c|}{ Number (\%) of patients } & \multicolumn{2}{|c|}{$\begin{array}{l}\text { Number }(\%) \text { of patients with HSV-1- } \\
\text { related tracheobronchitis or pneumonia }\end{array}$} & \multirow[t]{2}{*}{$P$ value $^{a}$} & \multirow[t]{2}{*}{ Relative risk } \\
\hline & Without risk factor & With risk factor & Without risk factor & With risk factor & & \\
\hline Age $\geq$ median (64 years) & $27(51.9)$ & $25(48.1)$ & $2(7.4)$ & $5(20.0)$ & 0.24 & 2.70 \\
\hline Gender, male & $15(28.8)$ & $37(71.2)$ & $1(6.6)$ & $6(16.2)$ & 0.66 & 2.43 \\
\hline $\begin{array}{l}\text { Simplified Acute Physiology Score > } \\
\text { median (31) }\end{array}$ & $27(51.9)$ & $25(48.1)$ & $2(7.4)$ & $5(20.0)$ & 0.24 & 2.70 \\
\hline $\begin{array}{l}\text { Time at risk on SICU > median } \\
\text { (8.5 days) }\end{array}$ & $26(50.0)$ & $26(50.0)$ & $1(3.9)$ & $6(23.1)$ & 0.10 & 6.00 \\
\hline Ventilation time $>$ median $(4.7 \text { days })^{\mathrm{b}}$ & $26(50.0)$ & $26(50.0)$ & $0(0)$ & $7(26.9)$ & 0.01 & - \\
\hline Bronchoscopy & $24(46.1)$ & $28(53.9)$ & $3(12.5)$ & $4(14.3)$ & 1.00 & 1.14 \\
\hline $\begin{array}{l}\text { Number of bronchoscopies }>\text { median } \\
\text { (1) }\end{array}$ & $37(71.1)$ & $15(28.9)$ & $4(10.8)$ & $3(20.0)$ & 0.40 & 1.85 \\
\hline Tracheotomy & $46(88.5)$ & $6(11.5)$ & $4(8.7)$ & $3(50.0)$ & 0.03 & 5.75 \\
\hline Reintubation & $37(71.1)$ & $15(28.9)$ & $4(10.8)$ & $3(20.0)$ & 0.40 & 1.85 \\
\hline Reanimation & $44(84.6)$ & $8(15.4)$ & $5(11.4)$ & $2(25.0)$ & 0.29 & 2.20 \\
\hline \multicolumn{7}{|l|}{ Underlying disease } \\
\hline Cardiomyopathyb & $48(92.3)$ & $4(7.7)$ & $7(14.6)$ & $0(0)$ & 1.00 & - \\
\hline Valvular heart disease & $35(67.3)$ & $17(32.7)$ & $6(17.1)$ & $1(5.9)$ & 0.40 & 0.34 \\
\hline Cystic fibrosis ${ }^{b}$ & $51(98.1)$ & $1(1.9)$ & $7(13.7)$ & $0(0)$ & 1.00 & - \\
\hline Infrarenal aortic aneurysm & $47(90.4)$ & $5(9.6)$ & $6(12.8)$ & $1(20.0)$ & 0.53 & 1.57 \\
\hline Suprararenal aortic aneurysm & $47(90.4)$ & $5(9.6)$ & $6(12.8)$ & $1(20.0)$ & 0.53 & 1.57 \\
\hline Coronary heart disease & $37(71.1)$ & $15(28.9)$ & $3(8.11)$ & $4(26.7)$ & 0.17 & 3.29 \\
\hline Congenital valvular heart disease ${ }^{b}$ & $48(92.3)$ & $4(7.7)$ & $7(14.6)$ & $0(0)$ & 1.00 & - \\
\hline \multicolumn{7}{|l|}{ Surgical intervention } \\
\hline Solid organ transplantation ${ }^{b}$ & $44(84.6)$ & $8(15.4)$ & $7(19.9)$ & $0(0)$ & 0.58 & - \\
\hline Left ventricular assist device & $43(82.7)$ & $9(17.3)$ & $5(11.6)$ & $2(22.2)$ & 0.59 & 1.91 \\
\hline Coronary artery bypass graft & $38(73.1)$ & $14(26.9)$ & $4(10.5)$ & $3(21.4)$ & 0.37 & 2.04 \\
\hline Aortic surgery & $41(78.8)$ & $11(21.2)$ & $5(12.2)$ & $2(18.2)$ & 0.63 & 1.49 \\
\hline Valve surgery & $37(71.1)$ & $15(28.9)$ & $6(16.2)$ & $1(6.7)$ & 0.66 & 0.41 \\
\hline Immunosuppressive medication & $27(51.9)$ & $25(48.1)$ & $5(18.5)$ & $2(8.0)$ & 0.42 & 0.43 \\
\hline Steroids & $28(53.8)$ & $24(46.2)$ & $5(17.9)$ & $2(8.3)$ & 0.43 & 0.47 \\
\hline Cyclosporinb & $46(88.5)$ & $6(11.5)$ & $7(15.2)$ & $0(0)$ & 0.58 & - \\
\hline Mycophenolate mofetilb & $44(84.6)$ & $8(15.4)$ & $7(15.9)$ & $0(0)$ & 0.58 & - \\
\hline Basiliximabb $^{b}$ & $46(88.5)$ & $6(11.5)$ & $7(15.2)$ & $0(0)$ & 0.58 & - \\
\hline Tacrolimus & $48(92.3)$ & $4(7.7)$ & $6(12.5)$ & $1(25.0)$ & 0.45 & 2.00 \\
\hline Blood products ${ }^{b}$ & $2(3.8)$ & $50(96.2)$ & $0(0)$ & $7(14.0)$ & 1.00 & - \\
\hline Erythrocyte concentrates ${ }^{b}$ & $8(15.4)$ & $44(84.6)$ & $0(0)$ & $7(15.9)$ & 0.58 & - \\
\hline Fresh frozen plasmab & $4(7.7)$ & $48(92.3)$ & $0(0)$ & $7(14.6)$ & 1.00 & - \\
\hline Thrombocyte concentrates & $15(28.8)$ & $37(71.2)$ & $2(13.3)$ & $5(13.5)$ & 1.00 & 1.01 \\
\hline $\begin{array}{l}\text { Number of erythrocyte concentrates } \\
>\text { median (7) }\end{array}$ & $27(51.9)$ & $25(48.1)$ & $1(3.7)$ & $6(24.0)$ & 0.05 & 6.48 \\
\hline $\begin{array}{l}\text { Number of fresh frozen plasma units } \\
>\text { median (11.5) }\end{array}$ & $26(50.0)$ & $26(50.0)$ & $1(3.9)$ & $6(23.1)$ & 0.09 & 6.00 \\
\hline $\begin{array}{l}\text { Number of thrombocyte } \\
\text { concentrates }>\text { median (3) }\end{array}$ & $26(50.0)$ & $26(50.0)$ & $3(11.5)$ & $4(15.4)$ & 1.00 & 1.33 \\
\hline Clotting factor substitution & $31(59.6)$ & $21(40.4)$ & $2(6.5)$ & $5(23.8)$ & 0.10 & 3.69 \\
\hline C1 esterase inhibitorb & $49(94.2)$ & $3(5.8)$ & $7(14.3)$ & $0(0)$ & 1.00 & - \\
\hline \multicolumn{7}{|l|}{ Interactions } \\
\hline $\begin{array}{l}\text { Ventilation time }>\text { median with } \\
\text { tracheotomy }\end{array}$ & $48(92.3)$ & $4(7.7)$ & $4(8.3)$ & $3(75.0)$ & 0.006 & 9.00 \\
\hline
\end{tabular}

aFisher's exact test. bVariable could not be included in the logistic regression model for mathematical reasons. 
Frequency of outcome death depending on patient characteristics and extrinsic risk factors

\begin{tabular}{|c|c|c|c|c|c|c|}
\hline \multirow[t]{2}{*}{ Risk factor } & \multicolumn{2}{|c|}{ Number (\%) of patients } & \multicolumn{2}{|c|}{$\begin{array}{l}\text { Number (\%) of patients } \\
\text { with outcome death }\end{array}$} & \multirow[t]{2}{*}{$P$ value $^{a}$} & \multirow[t]{2}{*}{ Relative risk } \\
\hline & Without risk factor & With risk factor & Without risk factor & With risk factor & & \\
\hline Age $\geq$ median ( 64 years) & $27(51.9)$ & $25(48.1)$ & $8(29.6)$ & $7(28.0)$ & 1.00 & 0.95 \\
\hline Gender, male & $15(28.8)$ & $37(71.2)$ & $4(26.7)$ & $11(29.7)$ & 1.00 & 1.12 \\
\hline $\begin{array}{l}\text { Simplified Acute Physiology Score }> \\
\text { median (31) }\end{array}$ & $27(51.9)$ & $25(48.1)$ & $6(22.2)$ & $9(36.0)$ & 0.36 & 1.62 \\
\hline Time at risk on SICU > median ( 8.5 days) & $26(50.0)$ & $26(50.0)$ & $5(19.2)$ & $10(38.5)$ & 0.22 & 2.00 \\
\hline Ventilation time $>$ median ( 4.7 days) & $26(50.0)$ & $26(50.0)$ & $2(7.7)$ & $13(50.0)$ & 0.002 & 6.50 \\
\hline Bronchoscopy & $24(46.1)$ & $28(53.9)$ & $3(12.5)$ & $12(42.9)$ & 0.03 & 3.43 \\
\hline Number of bronchoscopies $>$ median (1) & $37(71.1)$ & $15(28.9)$ & $10(27.0)$ & 5 (33.3) & 0.74 & 1.23 \\
\hline Tracheotomy & $46(88.5)$ & $6(11.5)$ & $11(23.9)$ & $4(66.7)$ & 0.05 & 2.79 \\
\hline Reintubation & $37(71.1)$ & $15(28.9)$ & $10(27.0)$ & 5 (33.3) & 0.74 & 1.23 \\
\hline Reanimation & $44(84.6)$ & $8(15.4)$ & $12(27.3)$ & $3(37.5)$ & 0.68 & 1.38 \\
\hline \multicolumn{7}{|l|}{ Cardiovascular disease } \\
\hline Cardiomyopathy ${ }^{b}$ & $48(92.3)$ & $4(7.7)$ & 15 (31.3) & $0(0)$ & 0.31 & - \\
\hline Valvular heart disease & $35(67.3)$ & $17(32.7)$ & $11(31.4)$ & $4(23.5)$ & 0.75 & 0.75 \\
\hline Cystic fibrosisb & $51(98.1)$ & $1(1.9)$ & $15(29.4)$ & $0(0)$ & 1.00 & - \\
\hline Infrarenal aortic aneurysm & $47(90.4)$ & $5(9.6)$ & $13(27.7)$ & $2(40.0)$ & 0.62 & 1.45 \\
\hline Suprararenal aortic aneurysm & $47(90.4)$ & $5(9.6)$ & $14(29.8)$ & $1(20.0)$ & 1.00 & 0.67 \\
\hline Coronary heart disease & $37(71.1)$ & $15(28.9)$ & $8(21.6)$ & $7(46.7)$ & 0.10 & 2.16 \\
\hline Congenital valvular heart disease & $48(92.3)$ & $4(7.7)$ & $14(29.2)$ & $1(25.0)$ & 1.00 & 0.86 \\
\hline \multicolumn{7}{|l|}{ Surgical intervention } \\
\hline Solid organ transplantation & $44(84.6)$ & $8(15.4)$ & $14(31.8)$ & $1(12.5)$ & 0.41 & 0.39 \\
\hline Left ventricular assist device & $43(82.7)$ & $9(17.3)$ & $12(27.9)$ & 3 (33.3) & 0.71 & 1.19 \\
\hline Coronary artery bypass graft & $38(73.1)$ & $14(26.9)$ & $9(23.7)$ & $6(42.9)$ & 0.19 & 1.81 \\
\hline Aortic surgery & $41(78.8)$ & $11(21.2)$ & $12(29.3)$ & $3(27.3)$ & 1.00 & 0.93 \\
\hline Valve surgery & $37(71.1)$ & $15(28.9)$ & $12(32.4)$ & $3(20.0)$ & 0.51 & 0.62 \\
\hline Immunosuppression & $27(51.9)$ & $25(48.1)$ & 9 (33.3) & $6(24.0)$ & 0.55 & 0.72 \\
\hline Steroids & $28(53.8)$ & $24(46.2)$ & $10(35.7)$ & $5(20.8)$ & 0.36 & 0.58 \\
\hline Cyclosporin & $46(88.5)$ & $6(11.5)$ & $14(30.4)$ & $1(16.7)$ & 0.66 & 0.55 \\
\hline Mycophenolate mofetil & $44(84.6)$ & $8(15.4)$ & $14(31.8)$ & $1(12.5)$ & 0.41 & 0.39 \\
\hline Basiliximab & $46(88.5)$ & $6(11.5)$ & $14(30.4)$ & $1(16.7)$ & 0.66 & 0.55 \\
\hline Tacrolimus & $48(92.3)$ & $4(7.7)$ & $14(29.2)$ & $1(25.0)$ & 1.00 & 0.86 \\
\hline Blood products ${ }^{b}$ & $2(3.8)$ & $50(96.2)$ & $0(0)$ & $15(30.0)$ & 1.00 & - \\
\hline Erythrocyte concentrates & $8(15.4)$ & $44(84.6)$ & $1(12.5)$ & $14(31.8)$ & 0.41 & 2.55 \\
\hline Fresh frozen plasmab & $4(7.7)$ & $48(92.3)$ & $0(0)$ & 15 (31.3) & 0.31 & - \\
\hline Thrombocyte concentrates & $15(28.8)$ & $37(71.2)$ & $2(13.3)$ & $13(35.1)$ & 0.18 & 2.64 \\
\hline $\begin{array}{l}\text { Number of erythrocyte concentrates > } \\
\text { median (7) }\end{array}$ & $27(51.9)$ & $25(48.1)$ & $4(14.8)$ & $11(44.0)$ & 0.03 & 2.97 \\
\hline $\begin{array}{l}\text { Number of fresh frozen plasma units }> \\
\text { median (11.5) }\end{array}$ & $26(50.0)$ & $26(50.0)$ & $4(15.4)$ & $11(42.3)$ & 0.06 & 2.75 \\
\hline $\begin{array}{l}\text { Number of thrombocyte concentrates > } \\
\text { median (3) }\end{array}$ & $26(50.0)$ & $26(50.0)$ & $4(15.4)$ & $11(42.3)$ & 0.06 & 2.75 \\
\hline Clotting factors & $31(59.6)$ & $21(40.4)$ & $6(19.4)$ & 9 (42.9) & 0.12 & 2.21 \\
\hline C1 esterase inhibitor & $49(94.2)$ & $3(5.8)$ & $13(26.5)$ & $2(66.7)$ & 0.20 & 2.51 \\
\hline $\begin{array}{l}\text { Herpes simplex virus-related } \\
\text { tracheobronchitis or pneumoniab }\end{array}$ & $45(86.5)$ & 7 (13.5) & $8(17.8)$ & $7(100)$ & $\begin{array}{l}<0.000 \\
1\end{array}$ & - \\
\hline Pneumonia & $46(88.5)$ & $6(11.5)$ & $11(23.9)$ & $4(66.7)$ & 0.05 & 2.79 \\
\hline
\end{tabular}

aFisher's exact test. bVariable could not be included in the logistic regression model for mathematical reasons. 
additionally as risk factors for fatal outcome. As appropriate to analyse the time period at risk for developing HSV-related tracheobronchitis or pneumonia, variables were only regarded as positive if they occurred prior to HSV detection (for patients with HSV-related tracheobronchitis or pneumonia) or prior to SICU discharge (for patients without HSV-related tracheobronchitis or pneumonia).

\section{Statistical analysis}

Univariable analysis and logistic regression with stepwise (forward and backward) variable selection were performed using SAS software (SAS Institute, Inc., Cary, NC, USA). $P<0.05$ was regarded as significant for univariable analysis. A significance level of 0.1 was chosen for inclusion of variables into a logistic regression model and for remaining included in the model.

The area under the receiver operating characteristic curve ( $c$ index) is used to evaluate the predictive power of the logistic regression model. The $c$ index represents the probability that the regression model equation assigns randomly chosen patients with HSV higher probabilities of acquiring HSV than randomly chosen patients without HSV [13].

\section{Viral diagnostics and molecular typing}

Respiratory specimens (bronchoalveolar lavage or tracheal aspirates in most cases, nasopharyngeal swab in one patient) were submitted to direct immunofluorescence staining with antibodies specific for HSV. A sample (1-2 ml) of the specimen was added to cell cultures of Hep-2 and Vero cells, and was monitored twice weekly for up to 3 weeks for emergence of a cytopathic effect. DNA was isolated and a real-time PCR was performed, detecting a $254 \mathrm{bp}$ fragment of the HSV UL27 gene (Engelmann, I., Petzold, D.R., Kosinska A., Hepkema B.G., Schulz, T. F. and Heim, A., accepted for publication in Journal of Medical Virology; Title: Rapid quantitative PCR assays for the simultaneous detection of herpes simplex virus, varicella zoster virus, cytomegalovirus, Epstein Barr virus and human herpesvirus 6 DNA in blood and other clinical specimens). Melting curve analysis was used to differentiate HSV-1 and HSV-2.

All viruses recovered from patients on the SICU during the time period of the cluster (designated C; Figure 1) - including patients with HSV-related tracheobronchitis or pneumonia and one patient with asymptomatic HSV detection - were typed. Additionally, HSV isolates from patients of the same SICU outside the cluster period (designated I) and HSV isolates from patients on other wards (designated $M$ ) were typed. A hypervariable part of the HSV-1 glycoprotein G was amplified as described by Rekabdar and colleagues [14]. Direct sequencing was performed using the PCR primers and the dRhodamine Terminator Cycle Sequencing Ready Reaction Kit (Applied Biosystems, Foster City, CA, USA) according to the manufacturer's instructions on the ABI PRISM 310
Genetic Analyzer (Applied Biosystems, Foster City, CA, USA). If direct sequencing was unsuccessful the samples were subjected to a nested PCR. The first round involved the amplification of a 600 bp fragment using the outer primers HSV-N1-For (5'-GGGTTCCCACCAACGTCTCC) and HSV-N1-Rev (5'GGGTGTGTGCGTCGCCCGC). The resulting PCR product was used as template in the PCR described above.

The nucleotide sequences have been submitted to the NCBI database GenBank (accession numbers EF376300EF376333).

Phylogenetic analysis of the $309 \mathrm{bp}$ sequence of the PCR product was conducted with Phylip software (version 3.63) and with the MEGA Software package (version 3.1) [15]. The phylogenetic tree was constructed using the neighbour-joining method (Kimura two-parameter matrix) with a transition/ transversion ratio of 2.0. Bootstrapping was performed with 1,000 replicates and values above $80 \%$ are indicated. The tree is presented as an unrooted tree because the use of HSV2 as an outgroup was impossible due to highly divergent sequences between HSV-1 and HSV-2 in the analysed region.

\section{Results}

HSV-related tracheobronchitis was diagnosed in six patients on a SICU within 8 weeks. Endobronchial bleeding was lifethreatening in three patients. HSV-1 was detectable in the respiratory specimens of all patients (Tables 1 and 2) whereas no concurrent bacterial or fungal pathogens were isolated. Furthermore, HSV-1 was detected in bronchoalveolar lavages of two additional patients who did not suffer from HSV-related tracheobronchitis, one of whom had pneumonia (Figure 1). The only surviving patient (C3) had neither clinical nor bronchoscopic signs of HSV-related tracheobronchitis but did receive antiviral medication.

All patients were HSV IgG-positive at the time of HSV detection, suggesting that none of them suffered from primary infection.

\section{Cohort study}

In order to confirm that HSV-related tracheobronchitis or pneumonia was associated with a higher mortality, and to identify risk factors for this entity, a cohort study including 52 patients (after exclusion of one patient with HSV detection in bronchoalveolar lavage but without symptoms related to HSV) was performed. Tables 3 and 4 present the results of univariable analysis for the outcomes HSV-related tracheobronchitis or pneumonia and death. Multiple logistic regression analysis revealed statistical association of HSV-related tracheobronchitis or pneumonia with the interaction between longer dura- 
tion of ventilation and tracheotomy, and statistical association

Table 5

\begin{tabular}{|c|c|c|}
\hline Variable & Adjusted odds ratio & $95 \%$ confidence interval \\
\hline \multicolumn{3}{|c|}{ Outcome herpes simplex virus-related tracheobronchitis or pneumonia } \\
\hline Interaction of ventilation time $>$ median with tracheotomy & 32.8 & $2.72-1000$ \\
\hline Number of erythrocyte concentrates $>$ median (7) & 8.16 & $0.96-226.4$ \\
\hline \multicolumn{3}{|l|}{$c$ index 0.867} \\
\hline \multicolumn{3}{|l|}{ Outcome death } \\
\hline Ventilation time $>$ median ( 4.7 days) & 30.7 & 3.3-892.7 \\
\hline Bronchoscopy & 19.8 & $2.2-536.6$ \\
\hline Number of thrombocyte concentrates $>$ median (3) & 16.3 & $2.1-388.7$ \\
\hline
\end{tabular}

Significance level for inclusion of variables in the model and for remaining included in the model was 0.1. (For mathematical reasons, herpes simplex virus-related tracheobronchitis or pneumonia could not be included in the model for outcome death.)

of HSV-related tracheobronchitis or pneumonia with the transfusion of a higher number of erythrocyte concentrates (Table 5).

Fatal outcome was associated with longer duration of ventilation, with bronchoscopy and with higher number of thrombocyte concentrate transfusions in multiple logistic regression analysis (Table 5). For mathematical reasons HSV-related tracheobronchitis or pneumonia could not be included as a risk factor in the logistic regression model, although it was the most significant risk factor in univariable analysis (Table 4).

No other examined variable showed a significant association with fatal outcome or with HSV-related tracheobronchitis or pneumonia in multiple logistic regression analysis.

\section{Molecular epidemiology}

To address the question of endogenous reactivation versus nosocomial transmission, all cluster patients' viruses were subjected to molecular typing. Sequencing of the hypervariable region of the viral glycoprotein $G$ revealed that patients' viruses fell into two groups, with viral sequences of patients $\mathrm{C} 2$ and $\mathrm{C} 3$ grouping together and with viral sequences of patients $\mathrm{C} 1, \mathrm{C} 7$ and $\mathrm{C} 8$ grouping together (Figures 2 and 3). Three cluster patients' viral isolates showed HSV-1 sequences that were not detected in other cluster patients' viral isolates (isolates C4, C5 and C6; Figure 2).

As some viral genotypes are known to predominate even in epidemiologically unrelated samples [16], analysis was extended to other HSV isolates obtained during approximately the same time period in the same hospital. Epidemiologically unrelated virus isolates (isolates 12, 16, 18, M4, M6, M7, M9, $\mathrm{M} 12$ and $\mathrm{M} 13$ ) that showed sequences identical to those of the cluster patients were found in the group represented by viral sequences $\mathrm{C} 1, \mathrm{C} 7$ and $\mathrm{C} 8$ (Figures 2 and 3). Viral sequences of patients $\mathrm{C} 2$ and $\mathrm{C} 3$, however, showed a unique sequence that was not identified in any of the epidemiologically unrelated isolates and could not be found in the NCBI database. The $\mathrm{C} 2 / \mathrm{C} 3$ viral sequence was characterized by a deletion of six base pairs in a repeat region and a point mutation at position 110 (of the alignment of partial glycoprotein $\mathrm{G}$ sequences) (Figure 3). Isolate $\mathrm{C} 2$ was obtained from a patient with HSV-related tracheobronchitis. In contrast to that, the patient from whom the viral sequence C3 was recovered did not show symptoms associated with HSV detection. Those two patients had overlapping stays on the SICU, and HSV was detected in their bronchoalveolar lavages on consecutive days (Figure 1).

Two out of 11 bronchoscope samples tested positive in the HSV real-time PCR and were also subjected to the HSV glycoprotein G PCR and the nested glycoprotein G PCR. A PCR product and sequence was obtained in only one case (viral sequence B1; Figures 2 and 3). The viral sequence B1 clustered with patient isolate $\mathrm{C} 6$ and a group of other isolates not epidemiologically related.

\section{Discussion}

HSV-1 detection in respiratory fluids of critically ill patients is frequently reported but its clinical relevance is often uncertain [5,7-9]. In our report the clinical relevance of HSV-1 detection in the respiratory tract is clearly shown by the fact that six out of eight patients with HSV-1 detection in their respiratory tract presented with haemorrhagic tracheobronchitis and four of the eight patients showed radiologic evidence of pneumonia. Only one out of eight patients had no symptoms or signs consistent with HSV-1 infection (patient C3); this patient received 
Figure 2

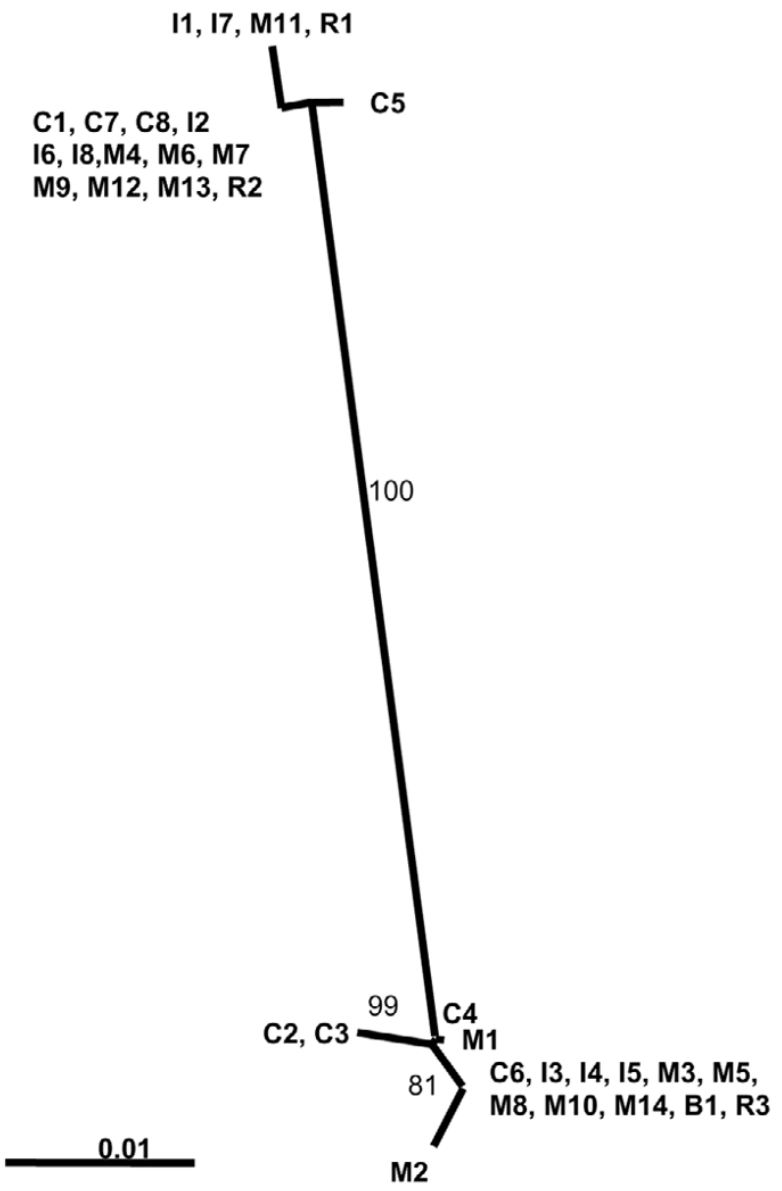

Neighbour-joining tree of partial herpes simplex virus type 1 glycoprotein $\mathrm{G}$ sequences. Numbers indicate percentage bootstrap values (only shown if $>80$ ). Scale bar indicates $1 \%$ genetic divergence. C, cluster patients' viral sequences; I, surgical intensive care unit patients' viral sequences; $M$, viral sequences from patients from other wards; $B$, viral sequence recovered from brochoscope; $R$, reference strains $(R 1=$ $17+, R 2=F, R 3=$ Kos).

ganciclovir prophylaxis as part of a postlung-transplant care regimen, which might have prevented development of a clinically relevant HSV-1 infection and might be the reason why virus culture was negative. Furthermore, the clinical relevance of HSV-related tracheobronchitis or pneumonia in critically ill patients is shown by its association with significantly increased mortality compared with patients without HSV-related tracheobronchitis or pneumonia (100\% versus $17.8 \%, P<0.0001$; Table 4). We therefore conclude that HSV-1 reactivation in the respiratory tract accompanied by tracheobronchitis or pneumonia is clinically relevant and is associated with high mortality. It is not possible, however, to prove to which extent HSV-related tracheobronchitis or pneumonia contributed to the fatal outcome in our patients because all patients suffered from other severe medical conditions.
In agreement with our results a recent study showed that lower respiratory tract infection with HSV was associated with poorer outcome (prolonged duration of mechanical ventilation and intensive care unit stay as well as more episodes of bacterial ventilator-associated pneumonia), although it was not associated with increased mortality in their patient cohort [17]. Interestingly, the clinical picture was different, as tracheobronchial bleeding was not described as one of the predominant symptoms [17].

Antiviral therapy with acyclovir initiated after diagnosis of HSV1 had been established in five of eight patients on average 2.9 days before death (data not shown). The therapy initiation, however, seems to have been too late to improve outcome. In case of endobronchial bleedings or bronchoscopic signs of haemorrhagic tracheobronchitis, therefore, acyclovir treatment should be initiated directly after bronchoscopy and specimen sampling (prior to diagnosis of HSV-1 infection), which would have been on average 8.6 days prior to death in our collective (data not shown).

Surgical procedures and critical illness result in immune dysfunction [18,19], which can be regarded as a predisposing factor for HSV reactivation in the patients described here. The vagal ganglia are thought to be the source of lower respiratory and oesophageal HSV reactivation [20]. Mucosal damage caused by intubation and mechanical ventilation, thoracic surgery or aspiration has been hypothesized to favour HSV reactivation $[5,11,17,21,22]$. Our observation that the interaction between longer duration of ventilation and tracheotomy (which was performed under bronchoscopic assistance) was a risk factor for HSV-related tracheobronchitis or pneumonia in logistic regression analysis may be explained by inoculation of HSV-1-positive fluids from the upper respiratory tract via bronchoscopically assisted tracheotomy or by mechanical airway irritation as a possible stimulus of reactivation. Whether longer duration of ventilation or tracheotomy alone represent significant risk factors for HSV-related tracheobronchitis or pneumonia remains unclear because they were not identified as independent risk factors in logistic regression analysis, and we cannot exclude that the interaction between longer duration of ventilation and tracheotomy indicates the severity of disease.

The most significant risk factor for fatal outcome identified in univariable analysis was HSV-related tracheobronchitis or pneumonia $(P<0.0001$, Table 4$)$. Owing to the fact that all patients with HSV-related tracheobronchitis or pneumonia died, this factor could not be included in the logistic regression model for mathematical reasons. Longer duration of ventilation, bronchoscopy and higher number of thrombocyte concentrate transfusions were associated with fatal outcome in the logistic regression analysis. These variables might be surrogate markers for more severe illness rather than risk factors. 
Partial alignment of herpes simplex virus type 1 glycoprotein $\mathrm{G}$ sequences. Black circles, unique polymorphisms in viral sequences $\mathrm{C} 2$ and $\mathrm{C} 3$. C, cluster patients' viral sequences; I, SICU patients' viral sequences; M, viral sequences from patients from other wards; $B$, viral sequence recovered from brochoscope ; $R$, reference strains ( $R 1=17+, R 2=F, R 3=K o s)$.

Our investigation has the following limitations. Owing to initiation of the analysis in a suspected outbreak situation, systematic testing of respiratory samples for HSV was not performed for all patients. The outcome was therefore defined clinically (that is, presence or absence of HSV-related tracheobronchitis or pneumonia) and not virologically (absence of HSV detection). HSV pneumonia or HSV-related tracheobronchitis was not confirmed by histopathology because, clinically, the presence of pneumonia or tracheobronchitis concurrent with HSV detection in respiratory fluids 
in the absence of other respiratory pathogens was regarded as sufficient for diagnosis and initiation of antiviral treatment. The size of the cohort is rather small, a limitation that is inherent to outbreak investigations.

Worthy of note is the fact that two bronchoscope samples had HSV-1 DNA detected after routine disinfection procedures. Typing was successful in only one case (viral sequence B1), which had a sequence identical to patient isolate C6 and to a number of epidemiologically unrelated virus isolates (Figures 2 and 3). The bronchoscope sample B1, however, was collected more than 2 months later than the positive specimen of patient isolate $\mathrm{C6}$. An epidemiological association is therefore unlikely. Furthermore, as no viable virus was recovered in virus culture, the significance of this finding concerning the possibility of transmission is uncertain. Testing of bronchoscope samples was initiated when the cluster was already recognized and first preventive measures had already been implemented. We therefore could not clarify whether bronchoscopes were the source of the suspected nosocomial transmission. Bronchoscopes, however, have been identified as sources of nosocomial transmission of other pathogens [23-26].

Studies examining HSV-1 detection in the respiratory tract of intensive care unit patients have assumed HSV-1 positivity to be caused by endogenous reactivation, and have not considered transmission although viruses were not typed [5,7-9]. HSV infections caused by nosocomial transmission, however, have been reported in different settings [27-35]. In those studies, viruses were typed by restriction fragment length polymorphism and almost identical restriction patterns have been interpreted as proof of transmission. That approach, however, does not take into account that some viral genotypes predominate in epidemiologically unrelated virus isolates [16]. Taking this fact into consideration we extended our sequence-based typing to epidemiologically unrelated virus isolates from the same hospital.

We found three cluster patients with HSV-1 sequences that were not detected in other cluster patients' viral isolates (isolates C4, C5 and C6; Figure 2). This finding favours endogenous reactivation as an underlying mechanism.

The group of three cluster patients with identical viral sequences also showed identical sequences to nine epidemiologically unrelated isolates and to the reference strain F (Figure 2). Furthermore, the epidemiological association between these three patients is weak (patient C1 stayed on the SICU at the beginning of the cluster, and patients $\mathrm{C} 7$ and $\mathrm{C} 8$ at the end; Figure 1). These findings favour the hypothesis that their viruses are part of the predominating genotypes. One patient pair (patients $\mathrm{C} 2$ and $\mathrm{C} 3$ ) that had a strong epidemiological association (overlapping stay in the SICU, HSV diagnosis on consecutive days; Figure 1) showed unique polymorphisms in the HSV glycoprotein G sequence that were not identified in any other sequenced isolates nor in the NCBI database. In this case we assume transmission to be likely. As both patients were lgG-positive prior to HSV detection this could represent nosocomial reinfection with a different virus strain. Patient C3 did not present with HSV-related tracheobronchitis but rather with asymptomatic HSV infection, possibly because the ganciclovir prophylaxis he received prevented development of a clinically relevant HSV infection.

As HSV isolates are not routinely typed it is possible that nosocomial transmission is not a rare event but might often not be recognized as such.

\section{Conclusion}

In the present article we have shown that HSV-related tracheobronchitis or pneumonia represents an important infectious complication in critically ill patients. This differential diagnosis has to be considered especially in the case of tracheobronchial haemorrhage or if the patient's condition does not improve with antibacterial and antifungal therapy. Whether acyclovir prophylaxis or early treatment in cases suspicious for HSV-related tracheobronchitis or pneumonia in critically ill patients has the potential of preventing fatal outcome should be addressed in future prospective studies.

\section{Key messages}

- HSV-related tracheobronchitis or pneumonia is associated with high mortality in critically ill patients.

- Tracheobronchial haemorrhage should prompt diagnostics for HSV.

- Molecular typing of virus isolates revealed one event of probable nosocomial transmission.

\section{Competing interests}

The authors declare that they have no competing interests.

\section{Authors' contributions}

IE participated in the design of the outbreak investigation, carried out the molecular genetic studies and the phylogenetic analysis, and wrote the manuscript. JG participated in the collection, interpretation and analysis of clinical data. AM participated in the collection, interpretation and analysis of clinical data. DS performed the statistical analysis. AR participated in the collection, interpretation and analysis of clinical data. $\mathrm{CH}$ $G$ participated in the phylogenetic analysis. PG participated in the study design, interpretation of data and drafting of the manuscript. TW participated in the interpretation of data and drafting of the manuscript. TFS participated in the study design, interpretation of the data and drafting of the manuscript. FM initiated the study, participated in the design of the study and in the interpretation and analysis of clinical data, and contributed to the writing of the manuscript. 


\section{Acknowledgements}

The author(s) would like to acknowledge the excellent technical assistance of Heidi Pommer and Marlies Werhane.

\section{References}

1. Adler SP: Herpes simplex virus. In Hospital Epidemiology and Infection Control Edited by: Marshall G. Philadelphia, PA: Lippincott Williams \& Wilkins; 2004.

2. Whitley RJ, Roizman B: Herpes simplex virus infections. Lancet 2001, 357:1513-1518.

3. Whitley RJ: Herpes simplex viruses. In Virology Edited by: Knipe DM, Howley PM. Philadelphia, PA: Lippincott Williams \& Wilkins; 2001.

4. Hatherley LI, Hayes K, Jack I: Herpes virus in an obstetric hospital. II: asymptomatic virus excretion in staff members. Med $J$ Aust 1980, 2:273-275.

5. Bruynseels P, Jorens PG, Demey HE, Goossens H, Pattyn SR, Elseviers MM, Weyler J, Bossaert LL, Mentens Y, leven M: Herpes simplex virus in the respiratory tract of critical care patients: a prospective study. Lancet 2003, 362:1536-1541.

6. Cook CH, Martin LC, Yenchar JK, Lahm MC, McGuinness B, Davies EA, Ferguson RM: Occult herpes family viral infections are endemic in critically ill surgical patients. Crit Care Med 2003, 31:1923-1929.

7. Cook CH, Yenchar JK, Kraner TO, Davies EA, Ferguson RM: Occult herpes family viruses may increase mortality in critically ill surgical patients. Am J Surg 1998, 176:357-360

8. Ong GM, Lowry K, Mahajan S, Wyatt DE, Simpson C, O'Neill HJ, McCaughey C, Coyle PV: Herpes simplex type 1 shedding is associated with reduced hospital survival in patients receiving assisted ventilation in a tertiary referral intensive care unit. $J$ Med Virol 2004, 72:121-125.

9. van den Brink JW, Simoons-Smit AM, Beishuizen A, Girbes AR, Strack van Schijndel RJ, Groeneveld AB: Respiratory herpes simplex virus type 1 infection/colonisation in the critically ill: marker or mediator? J Clin Virol 2004, 30:68-72.

10. Sherry MK, Klainer AS, Wolff M, Gerhard H: Herpetic tracheobronchitis. Ann Intern Med 1988, 109:229-233.

11. Klainer AS, Oud L, Randazzo J, Freiheiter J, Bisaccia E, Gerhard H: Herpes simplex virus involvement of the lower respiratory tract following surgery. Chest 1994, 106:8S-14S.

12. Roest RW, Carman WF, Maertzdorf J, Scoular A, Harvey J, Kant M, van der Meijden WI, Verjans GM, Osterhaus AD: Genotypic analysis of sequential genital herpes simplex virus type 1 (HSV-1) isolates of patients with recurrent HSV-1 associated genital herpes. J Med Virol 2004, 73:601-604.

13. Hanley JA, McNeil BJ: The meaning and use of the area under a receiver operating characteristic (ROC) curve. Radiology 1982, 143:29-36.

14. Rekabdar E, Tunback $P$, Liljeqvist JA, Bergstrom T: Variability of the glycoprotein $\mathbf{G}$ gene in clinical isolates of herpes simplex virus type 1. Clin Diagn Lab Immunol 1999, 6:826-831.

15. Kumar S, Tamura K, Nei M: MEGA3: integrated software for molecular evolutionary genetics analysis and sequence alignment. Brief Bioinform 2004, 5:150-163.

16. Sakaoka H, Kurita K, lida Y, Takada S, Umene K, Kim YT, Ren CS, Nahmias AJ: Quantitative analysis of genomic polymorphism of herpes simplex virus type 1 strains from six countries: studies of molecular evolution and molecular epidemiology of the virus. J Gen Virol 1994, 75(Pt 3):513-527.

17. Luyt CE, Combes A, Deback C, Aubriot-Lorton MH, Nieszkowska A, Trouillet JL, Capron F, Agut H, Gibert C, Chastre J: Herpes simplex virus lung infection in patients undergoing prolonged mechanical ventilation. Am J Respir Crit Care Med 2007, 175:935-942.

18. Howard RJ, Simmons RL: Acquired immunologic deficiencies after trauma and surgical procedures. Surg Gynecol Obstet 1974, 139:771-782.

19. Slade MS, Simmons RL, Yunis E, Greenberg LJ: Immunodepression after major surgery in normal patients. Surgery 1975 , 78:363-372.

20. Tuxen DV: Prevention of lower respiratory herpes simplex virus infection with acyclovir in patients with adult respiratory distress syndrome. Chest 1994, 106:28S-33S.
21. Hanley PJ, Conaway MM, Halstead DC, Rhodes LV III, Reed J III: Nosocomial herpes simplex virus infection associated with oral endotracheal intubation. Am J Infect Control 1993, 21:310-316.

22. Camps K, Jorens PG, Demey HE, Pattyn SR, leven M: Clinical significance of herpes simplex virus in the lower respiratory tract of critically ill patients. Eur J Clin Microbiol Infect Dis 2002, 21:758-759.

23. Corne $\mathrm{P}$, Godreuil S, Jean-Pierre H, Jonquet $\mathrm{O}$, Campos J, JumasBilak $\mathrm{E}$, Parer $\mathrm{S}$, Marchandin $\mathrm{H}$ : Unusual implication of biopsy forceps in outbreaks of Pseudomonas aeruginosa infections and pseudo-infections related to bronchoscopy. J Hosp Infect 2005, 61:20-26

24. Bou R, Aguilar A, Perpinan J, Ramos P, Peris M, Lorente L, Zuniga A: Nosocomial outbreak of Pseudomonas aeruginosa infections related to a flexible bronchoscope. J Hosp Infect 2006, 64:129-135.

25. Sorin M, Segal-Maurer S, Mariano N, Urban C, Combest A, Rahal $\mathrm{JJ}$ : Nosocomial transmission of imipenem-resistant Pseudomonas aeruginosa following bronchoscopy associated with improper connection to the Steris System 1 processor. Infect Control Hosp Epidemiol 2001, 22:409-413.

26. Michele TM, Cronin WA, Graham NM, Dwyer DM, Pope DS, Harrington S, Chaisson RE, Bishai WR: Transmission of Mycobacterium tuberculosis by a fiberoptic bronchoscope. Identification by DNA fingerprinting. JAMA 1997, 278:1093-1095.

27. Francis DP, Herrmann KL, MacMahon JR, Chavigny KH, Sanderlin $\mathrm{KC}$ : Nosocomial and maternally acquired herpesvirus hominis infections. A report of four fatal cases in neonates. $A m J$ Dis Child 1975, 129:889-893.

28. Linnemann CC Jr, Buchman TG, Light IJ, Ballard JL: Transmission of herpes-simplex virus type 1 in a nursery for the newborn. Identification of viral isolates by D.N.A. 'fingerprinting'. Lancet 1978, 1:964-966.

29. Adams G, Stover BH, Keenlyside RA, Hooton TM, Buchman TG, Roizman B, Stewart JA: Nosocomial herpetic infections in a pediatric intensive care unit. $A m$ J Epidemiol 1981, 113:126-132.

30. Hammerberg O, Watts J, Chernesky M, Luchsinger I, Rawls W: An outbreak of herpes simplex virus type 1 in an intensive care nursery. Pediatr Infect Dis 1983, 2:290-294.

31. Manzella JP, McConville JH, Valenti W, Menegus MA, Swierkosz $\mathrm{EM}$, Arens M: An outbreak of herpes simplex virus type I gingivostomatitis in a dental hygiene practice. JAMA 1984, 252:2019-2022.

32. Sakaoka H, Aomori T, Ozaki I, Ishida S, Fujinaga K: Restriction endonuclease cleavage analysis of herpes simplex virus isolates obtained from three pairs of siblings. Infect Immun 1984 , 43:771-774.

33. Van Dyke RB, Spector SA: Transmission of herpes simplex virus type 1 to a newborn infant during endotracheal suctioning for meconium aspiration. Pediatr Infect Dis 1984, 3:153-156.

34. Sakaoka H, Saheki Y, Uzuki K, Nakakita T, Saito H, Sekine K, Fujinaga K: Two outbreaks of herpes simplex virus type 1 nosocomial infection among newborns. J Clin Microbiol 1986, 24:36-40.

35. Perl TM, Haugen TH, Pfaller MA, Hollis R, Lakeman AD, Whitley RJ, Nicholson D, Hunter GA, Wenzel RP: Transmission of herpes simplex virus type 1 infection in an intensive care unit. Ann Intern Med 1992, 117:584-586. 